\title{
DISAPPEARANCE OF THE TRADITIONAL ARCHITECTURE - THE KEY STUDY OF STARA PLANINA VILLAGES
}

\section{A B S T R A C T}

This paper is focused on the disappearance of the traditional architecture in the Stara Planina villages, in the Pirot area, at the eastern border of Serbia. The paper gives authentic examples of traditional rural architecture with emblematic traditional elements and methods of construction, which have been gradually disappearing over time due to abandonment of the villages. Reasons leading to the villages withering away and the decay of architecture in that mountain area are predominantly enormous migrations of the village population to the cities as a result of socio-economic changes and poverty of the region. The abandonment of the villages leaves in its wake a sparse ageing population, housing units and other structures in the state of decay and ruin. In the past, the area was well-known as a source of native, self- taught, builders called dunđeri, organized in the groups of 10-15 people, tajva, famous and respected on the territories of Bulgaria, Romania and Serbia. Nowadays their descendants work and live in urban areas, and as a consequence, the villages have not preserved their traditional building skills. 


\section{INTRODUCTION}

In its geographical position, Stara Planina belongs to the continental part of the Balkan Peninsula. It represents the highest mountain in Eastern Serbia and serves as a natural border between Serbia and Bulgaria. Within the mountain relief it is possible to distinguish areas of villages Visok and Zabrdje, at the slopes of mountain Vidlič. Taking advantage of natural geographical benefits of the Stara Planina area, i.e. favourable temperate continental climate, relief and hydrographical features, the autochthonous population established its first primitive settlements at the foot of Stara Planina in the Neolithic (3.300-2.200 B.C.). According to their urban morphological structure, these settlements are classified as the so-called compact mountain villages, with a differentiation between river-mountain and river-valley subtypes. The marked villages belong to the Pirot area (with major towns of Dimitrovgrad and Pirot) (Fig. 1).

The second half of the $19^{\text {th }}$ century is considered to be a period of flourishing construction in the area, especially after the War in 1877-1878 and the liberation from the Ottomans rule. ${ }^{1}$ This authentic vernacular architecture in the area was introduced by the members of the native population, the self-taught folk builders (dundjeri), which were well-known as skilful builders in the entire Balkan region, as the skill was being spread thanks to migrant worker in other regions. The essence of the Stara Planina vernacular houses beauty lies in the traditional spatial and construction elements, and specific architectural and decorative elements. Today, the preserved vernacular architecture in the villages is mostly listed as valuable traditional cultural heritage of Serbia, but in decay and of an uncertain future. ${ }^{2}$

\section{THE MAIN INFLUENCES OF THE FAST DEVELOPMENT OF THE STARA PLANINA VILLAGES}

Traditional rural houses on Stara Planina date predominantly from the period of the second half of the 19th century and the first half of the 20th century, with some houses originating from the first half of the 19th century. ${ }^{3}$ A rich and diverse architecture was created depending on the following: the location of a village; its distance from nearest cities; transfer of the architectural elements from the cities; as well as demographic structure of population, i.e. number of Shop and Serbian population. For further development of the region, important moment after the WWI was when, according to the terms of the Treaty of Neuilly, signed on 27th November 1919, a substantial number of the Stara Planina villages, including Caribrod (today Dimitrovgrad), became part of the new country - Kingdom of Serbs, Croats and Slovenes, as opposed to the previous period when they had belonged to the Kingdom of Bulgaria. It should also be noted that 
these villages were in close vicinity of the one of the main historical road at the Balkan, as connection of West and East, which was known as the Via Militaris in Roman and Byzantine periods, or the Constantinople Road in the medieval time. During the Ottoman Empire, which ruled over the Balkan from the late 14th century, it was called Constantinople Road (Stambuldjol). In the present times, this is a railway route connecting Central Europe and the Middle East. ${ }^{4}$

The life of Stara Planina villagers has always been one of hardships and suffering. Agriculture and animal husbandry have been predominant from the earliest times. According to the 1900 census figures, 95\% of the population lived off agriculture, while only $5 \%$ were employed otherwise 5 . The causes of massive labour migrant were different, not only the natural ones (poor quality and decline of soil quality, harsh mountain climate, high birth rates, etc.), but also the socio-economic circumstances. Additional sources of income came from handicrafts, crafts and migrant work. Living in poverty, the village population was engaged in different kinds of migrant work, one of the most popular was the building skill (dundjerluk), and the builders were called dunđeri. Migrant work in Eastern Serbia appeared towards the end of the 18th century and was present until the 1830s. After the World War I, migrant working builders started to die out and remained only in the area of village Visok. Towards the end of the 19th century in Serbia, there were such a large number of migrant workers from Pirot and its surrounding area that the county and regional authorities were unable to follow their movements around the country. Over a thousand people would leave their villages every year to work in other regions, primarily in the wider area of Stare Planina, at Zagorje (Bulgaria), as well as in Vlaška (Rumania), Sofia (Bulgaria) and Serbia. ${ }^{6}$ The development and spread of migrant work was very positive for the Stara Planina villages and caused significant changes in the economic and social development of the vernacular architecture.




The builders from the Visok area (villages Zavojci, Brložani, Rosomačani and Slavinjčani) reached the greatest achievements in the traditional vernacular architecture, improving the traditional methods of a light-wood construction, or timber-framed (bondruk-style) construction, which was characteristic of east Balkan area during the Ottoman rule. ${ }^{7}$ The village of Slavinja was famous for some of the best-known builders (like Ilija Lilo Lazarov, etc.) whose influence on the monumental church architecture in Serbia and Bulgaria was analysed by Nikolaj Tuleškov in the book Slavinskite Prvomajstori. ${ }^{8}$ A great number of migrant workers came from the so-called villages with enough food, i.e. those villages which were able to satisfy the basic needs of their population, as Dojkinci, Brlog, Jelovica, Cerova and particularly the village of Šugrin, which had the most homogenous guilds of builders, who took care of good teaching of young builders, which resulted in high achievements in architectural expression in terms of form and space.

\section{THE REASONS OFTHE DECLINE OF VILLAGES AND TRADITIONAL ARCHITECTURE}

Following the liberation from the Ottoman rule in 1878, the Stara Planina region witnessed crucial historical, political and social events. These were the three Bulgarian occupations in a row - the first one during the SerbianBulgarian war in 1885, followed by the occupations in the WWI from 1915 to 1918 , which was followed by the changes caused by the implementation of the terms of the Treaty of Versailles. ${ }^{9}$ The socio-economic development of the region went through two phases. The first was in the interwar period with the initial capital accumulation and the development of capitalism. The division of Visok between Yugoslavia and Bulgaria, after the Treaty of Neuilly in 1919, diminished the economic power of the population. Customs houses and administrative authorities were introduced, followed by the spread of the city and foreign capital. Disintegration of patriarchal communities led to the creation of separate families which were unable to run big household and estates, which in its own turn caused the decomposition of these households into small ones. This gave rise to social stratification, i.e. the creation of the class of poor population and the class of wealthy villagers. In the interwar period, the formed cooperatives and estates underwent the process of stratification as well. In the post-World War II industrial expansion, agriculture and, consequently, animal husbandry were in a decay, which resulted in an era of intensive migrations from the villages to the cities ${ }^{10}$

The villages in the Stara Planina region (as well as a vast number of villages throughout Serbia) came to be abandoned in this process of enormous rural-urban 
migrations and were left with a small and mostly ageing population. Considering that this population did not carry out any renovations of old buildings, today the preserved houses are completely authentic, although in a state of deterioration due to the lack of maintenance. Sometimes, the construction of new houses or adaptations of the old ones meant that the traditional buildings were demolished just for purposes of using the building material. At the same time, traditional architecture is additionally degraded by unskilful alterations.

The remnants of once active life in villages are nowadays dilapidated schools and a few public buildings. In the summer months, urban population uses the houses of their ancestors for vacation, but these dwellings are abandoned for the most part of the year. Dispersion of mountain villages, as well as their inaccessibility and poor connections in the winter period, as well as a harsh climate, make the maintenance of the buildings more difficult. Poor infrastructure in these rural areas, modern comfortable and easier way of life in urban areas and economic reasons caused the old houses to be left for good.

Changes in socio-political, cultural and sociological life after the WWII caused mass emigrations of the population to major cities or abroad. The emigrations led to the decline of villages, consequently resulting in the disappearance of traditional architectural houses, which were already endangered by the application of new industrial building materials - such as brick, roof tile and concrete. Self-taught builders nowadays work and live in urban areas and as a consequence, besides the population declines, the villages are left without their traditional builders. ${ }^{11}$

A comparative overview of the population figures in villages according to the 'FPRY Census of 15th May 1948" and the "Census of population, households and dwellings in the Republic of Serbia in 2011" shows that in 1948 the population of the villages in the Visok and Zabrđe areas was 15,435 and 5,213 respectively, while these numbers declined to only 981 and 422, according to the 2011 census. ${ }^{12}$ This data very clearly illustrated enormous loss of the population in the post war period.

THE ARCHITECTURAL AND STYLISTIC ELEMENTS OF TRADITIONAL HOUSES IN THE AREA OF STARA PLANINA ${ }^{13}$

\section{VILLAGES IN THE AREA VISOK}

According to their geographic characteristics, the villages in the area of Visok are divided into the villages of Upper ${ }^{14}$, Middle ${ }^{15}$ and Lower Visok ${ }^{16}$. 
After the Second World War, the Village Gostuša had the highest population among the villages in the Visok area. It represents one of the so-called villages with enough food. Its population did not leave the village in search of migrant work, unlike in the cases of other villages in the area of Visok. It is worth noting that this was one of the villages with the most striking features, established as a highly dense composition that follows the relief and surface shapes and features. The houses have high cellar walls made of stone, and roofs exclusively covered by stone tiles. In almost every house there is an earthen cooking stove (vurnja) and a fireplace preserved, as well as some of the most beautiful examples of chests made of hand-hewn wooden boards. For the reasons of very intensive emigration, this dense architectural compostion looks derelict in the present times.

In terms of its natural attractions, the Village Rosomač is famous for Rosomački lonci - a canyon which the Rosomač river carved through the massifs. The village belongs to the type of compact mountain villages with a small population and a few authentic houses without porches called čatmare, which are typical for this village. The construction of these houses is a light timber structure, the so-called bondruk construction (with the basic timber frame consisted of the post and beam structure with trusses or braces supporting at corner points) filled with wattle daub (̌̌atma). ${ }^{17}$

The Kamenica River flows through the Village of Kamenica. Apart from its natural attractions, the village has a large number of deserted houses, today listed as cultural property, which are in a well-preserved condition owing to the good economic potential of the villagers in past. ${ }^{18}$ One of these is the House of Angel Ivanov, from 1880-1890, a light timber posts structure filled in with wattle and daub. ${ }^{19}$ The two-storey house has a porch (which was partially closed with walls and windows between). The porch has representative architectural elements and decoration - curved (holker) eaves and longitudinal eaves beam $(\text { ćenarka })^{20}$ with ornaments in a shape of Venetian teeth ${ }^{21}$. The specific value of the house is its decorative elements in the zone of the attic window. On the back facade, above the upper window, there is a short line of egg-shaped elements which are reminiscent of Ionian egg-shaped decoration. ${ }^{22}$ The origin of this decoration is very interesting, since its shape is specific and atypical of the common decorations in the villages of Stara Planina. The same applies to the coat of arms on the front façade above the upper window. The coat of arms has a decorative relief crown with two snakes whose heads are oriented towards the crown's base. Since the migrations in the village were very frequent (according to the house owners, people from Raška, Kosovo and Adriatic Coast 
were migrating and settling in the village in the 18th century), it is assumed that these migrations may account for the decorations on the house. (Fig. 2).

Located in the immediate vicinity of the village of Kamenica, the Village Senokos has some traditional houses, but they mostly underwent ignorant adaptations which impaired their authenticity.

The Village Slavinja in the past was well-known for its excellent native builders. The most famous among them was Ilija (Lilo) Lazarov who was the leading representative of the Slavinje building school. Building and related artistic and craftsman skills of those masters are visible in the village even today. For example, the porches of the abandoned houses have decorations on their blind arcades, with examples of stylized flowers with petals on the porch pillars, which points to an influence of representative urban architecture..$^{23}$

The Village Izatovci features a house called Čandino from the beginning of the 19th century, which has a two-storey dwelling with bay windows and an open gallery (doksat) upstairs. It is dilapidated, the same as many houses with traditional elements here. However, even the houses dating from more recent times, such as the House of Stavrija Tošev which was built in the classical academic style in 1934, are desolate and devastated in present times as well.

The Village Braćevci has many decaying houses. ${ }^{24}$ Rare examples of the wellpreserved tradition is a room with a fireplace in its middle - so-called $i z ̌ a$, in the House of Nikola Gerov, built in 1870, a number of traditional houses are in the state of ruin and devastation, such as the House of Vitomir Gerov, from 1900, the House of Jovanka Velkov, from 1910, and the House of Marjan Petrov, from 1920.

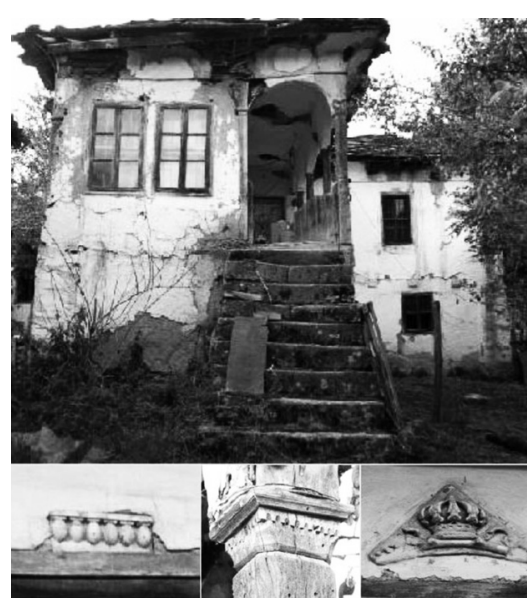

Figure 2. The house of Angel Ivanov, 1880-1890, Village of Kamenica (the entrance façade and the details of the decorative elements, below, credits: G. Ljubenov)

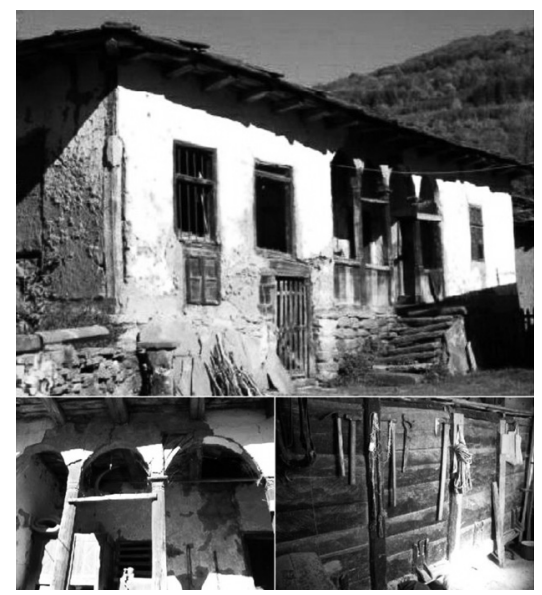

Figure 3. The house of Desimir Kostić, 1900, Village of Brlog (the entrance fasade and details of the porch with arches and wooden storage elements called preseci, below, credits: G. Ljubenov) 
The Villages Brlog and Dojkinci are in the immediate vicinity of the SmrčaArbinje reserve. A stream called Dojkinačka Reka runs through the villages and the lumber material is plentiful. Once in this area, there were a lot of lumber mills and woodworking shops for fine wood processing and chest making. A certain number of houses in Dojkinci were reconstructed, and stone roof coverings having been replaced by ceramics tiled roofs and the like. Some of the unique examples are still fully functional, such as the House of Jordan Petrović, from 1909, with $i z ̌ a$ and the fireplace (vurnja); as well as the House of Duško Mančić, which belongs to a type of the so-called houses with two chimneys.

Among the craftsmen from the Stara Planina villages, the villagers from the Village Brlog were the best-known carpenters. Beside the House of a carpenter Dimitrije Lilić, dating back to 1890; there are a number of abandoned "masterpieces" of vernacular architecture. The oldest one of two-parts, the House of Grafina Pavlović, was closed a long time ago; the House of Duško Kostić, from 1860, was built without the use of any nails, i.e. by applying only the wooden screws and wedges. This three-room timber framed wattle-and-daub structure has entrance porch in the central zone of façade, with decorated arches. In close vicinity is the House of Desimir Kostic from 1900, which apart from the decorations on the porch elements, in the storage room (called ciler), has wellpreserved wooden storage elements (called preseci) for corn and wheat. (Fig. 3)

The Village Boljev Dol is an extremely old and impressive village. ${ }^{25}$ The abandoned House of Angel Jocev from 1890, with a longitudinal porch and decorated wooden structure is an epitome of the traditional house with remarkable values as traditional architectural heritage. The early 20th architecture, with modern construction principles, is reflected in the House of Dmitar AleksovMarčin from 1920, which has decorative forms influenced by baroque.

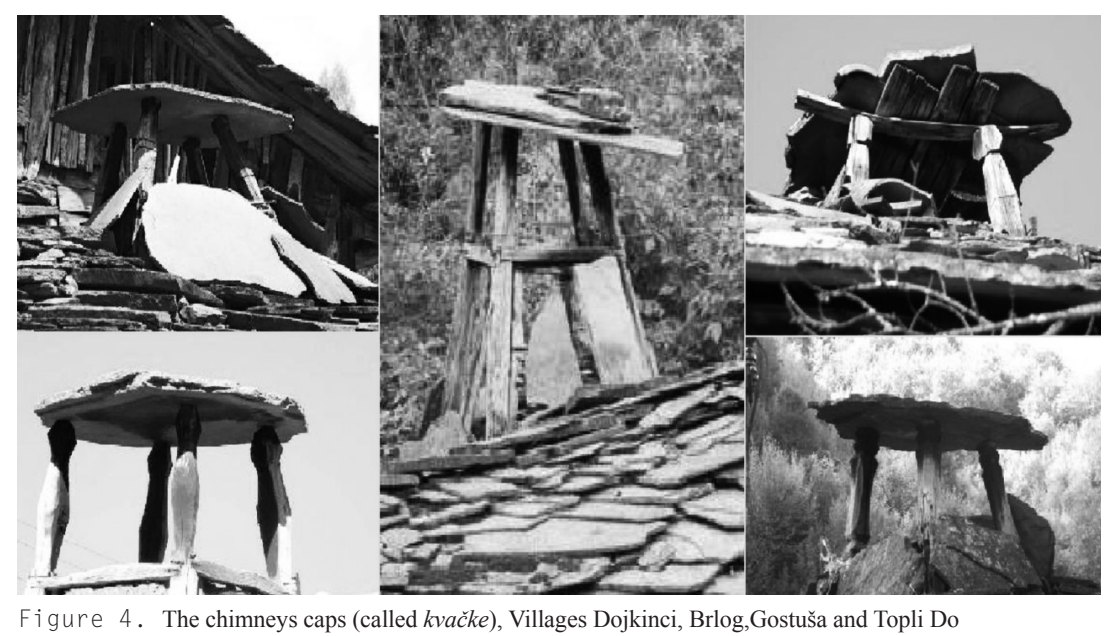


One of the numerous abandoned and devastated houses in the Village Donji Krivodol is the House of Nikola Ivanov from 1909, situated in the village centre, at the intersection of ancient roads and in the immediate vicinity of the Visočica river bank.

\section{The villages of Middle Visok}

The Village Pakleštica is well-known for woodworking skills of its craftsmen. On partially devastated old houses, we have still preserved decorative windows with adorning crosspieces, pillars and lintels on porches, which bear memory to the work of these craftsmen. The bondruk style houses are dominant (a light timber posts structure filled in with wattle and daub), with roof coverings of stone tiles and chimneys caps called kvačka. ${ }^{26}$ (Fig. 4) This village devastated houses bring a unique example of walls made of tufa stone. A typical representative is the House of Gojko Rančić from 1916, which used to belong to the Andonović family, structured as a three-room house. The chimney was made from stone pieces with lateral openings. Inside the house there is a preserved fireplace (vurnja) and a kitchen hood for removing smoke, made of wattle.

\section{The Villages of Lower Visok}

The Village Topli Do belongs to the river-mountain types of villages. The Toplodolska River which runs through the village had its impact on the village original structure. The prevailing red colour of the façade coating (a mixture of clay, mud and straw) came as a result of the presence of red sandstone in this area. The houses are timber framed structure with wattle-and-daub, or the so-called kovanice, from the beginning of the 20th century. Many one storey houses have structural oriel windows with visible wooden beams in the floor structure. A high level of stylization applied on wooden supports of stone slabs on the chimney tops, at the so-called kvačka, gives an impression that these, very precisely and carefully made architectural elements were an important expression of the village's tradition.

\section{VILLAGES IN THE AREA OF ZABRDJE}

A lot of households in the Village Mazgoš are desolate. The village has several decaying structures built during the liberation from the Turks period, like the House of Dimitri Džunov, dating from 1870. The house has a cellar and upstairs a longitudinal deep open gallery, the so called čardak, decorated with arcades, i.e. columns and arches with parapet. The eaves are arched (the so-called holker-eaves) and they originate from the urban architecture, while the roof covering is barrel tile. The open gallery (doksat) on the first floor is one of the characteristics of the eastern Balkan vernacular houses. 
In the Village Mojinci, with authentic traditional characteristics is the House of Asen Rusimov, dating to 1820 . This is a house with a porch at the corner and a raised gallery (doksat). The wooden columns are decorated in the upper part and in the area next to the parapet; the elaborately decorated lintels support the beam and a decaying ceiling above the porch and the raised gallery.

The architectural heritage in the Village Prtopopinci is neglected and devastated. Every structure has characteristic architectural elements which are in the state of decay. The house of Simeon Vasov from 1900 has the central entrance porch with arcades as a dominant spatial element. The builder's skills and inspiration in shaping and adorning the roof is impressive: ridge beams, purlins, rafters, roof eaves wooden decoration (ćenarka), etc.

The Village of Smilovci is one of the largest villages in the area of Zabrđe. The village has around 10 traditional houses kept in their original form along with preserved architectural elements - such as the wooden elements on top of the pediment, the so-called house-guard (čuvar kuća), a wooden collar beam with the pinnacle turned upwards ${ }^{28}$, curved eaves and an eaves wooden decoration. One of the most beautiful houses is a semi-detached one in the village centre, belonging to Mile Cenkov, from 1912. Apart from the vertical division of the structure and two dwellings with two separate entrances and a balcony with arcades above, the characteristic elements are holker eaves and eaves wooden decoration. The upper floor is accessed laterally due to the land slope. (Fig. 6) As architectural elements, balconies with or without non-structural arches are present only in the area of Zabrđe. ${ }^{29}$.

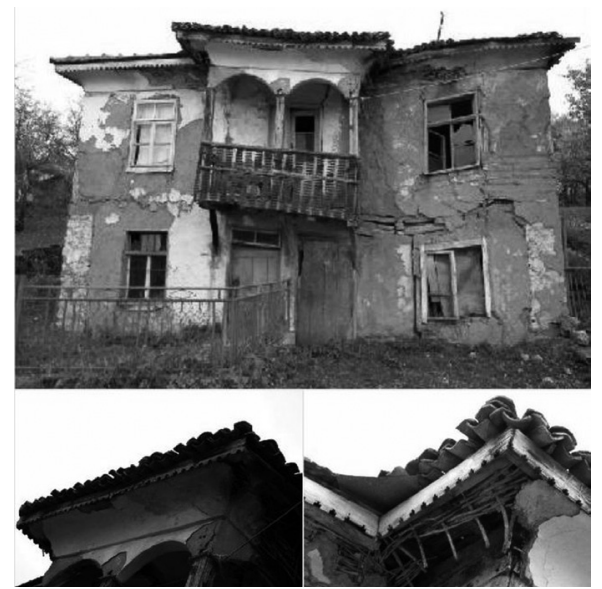

Figure 5. The house of Mile Cenkov,1912, village of Smilovci (the entrance façade and the details of the holker eaves, below, credits: G. Ljubenov)

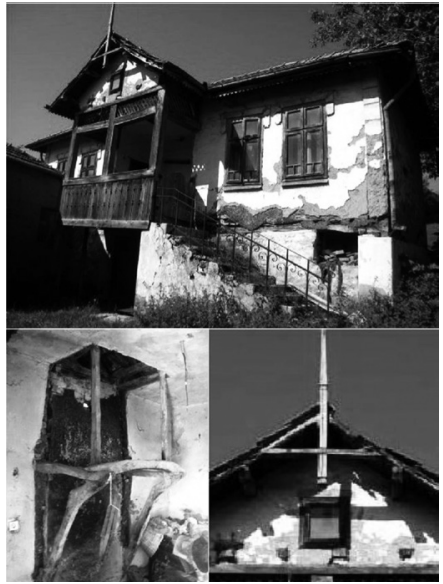

Figure 6. House of Arsenie Dimitrijević, 1932, Village of Radejna (the detail of fireplace, left, and pediment with the houseguard, right, credits: G. Ljubenov) 
In the Village Visocki Odorovci many of the houses are $\operatorname{closed}^{30}$. One of these is a well-preserved House of Dmitar Ivanov, from 1890, located in the centre of the village. Valuable architectural heritage and one of the village's attractions is an authentic woodworking shop from 1910, which used to belong to Jovan Jelenkov. The shop kept its traditional carpenter tools for making windows, doors, etc.

The Village Gulenovci is also rich in traditional architecture, but it's most valuable structures are nowadays forlorn and dilapidated, like the houses of Trajko Miladinov, of Trajko Lilov, of Ljuba Andrejev, etc. ${ }^{31}$

Among the abandoned houses in the Village Radejna, there are a number of traditional architectural structures worth mentioning and a substantial number of abandoned houses are in a good condition. The house of Arsenije Dimitrijević (now owned by Nikolajče Mančev) from 1932, is a structure with stone basement and an entrance porch with stone stairs, wooden columns and parapet, and a pediment (tympanum), with the house-guard (čuvar-kuća), in the centre of the façade. The façade is decorated with corner ornaments, window shapes, etc. This house type is identical to the type found in Dobrudža, Bulgaria. (Fig. 7)

The house of Rade Galev, from 1912, is a typical one, with a central arched porch, quite similar to the villages of Zabrđe and Visok, whereas the house of Todor Veličkov, from 1905, with open storey galleries (čardaci), and hidden second floor stairs, is a novelty in these areas, which testifies mobility of the traditional builders and transfer of influence from other Balkan areas.

\section{THE OTHER VILLAGES OF STARA PLANINA}

Apart from the areas of Visok and Zabrđe, some the villages of Stara Planina, located in the direction of Knjaževac, belong to the area called Budžak ${ }^{32}$.

Most houses in the Village Šugrin carry elements of traditional folk architecture. Façade decorations are of artistic and handicraft expressions, combined with traditional construction techniques, which make this village a unique one in its surroundings, reflecting the economic and cultural portrait of the population around the mid-20th century. Unfortunately, as in other villages, depopulation brought a decline in the villages' vitality and functionality. The house of Momir Ignjatović, from 1820, stands out among the other abandoned ones. It belongs to the group of the so-called eaves houses ${ }^{33}$ with longitudinal porch, with wooden columns in the front of the house, and two rooms inside the house. The roof is pitched and covered with barrel tiles. There is a wooden bed for relaxation on 
the raised gallery, the left part of the porch, which was used for napping during the summer months.

Some of the abandoned houses in the Village of Orlja are emblems of traditional architecture; one of them is the House of Mateja Kostić-Palavozov, from 1935, and the House of Aksentije Antić, etc.

The Village Oreovica is one of the so-called not-so-needy villages. Migrant workers from this type of villages left their homes in search for work, but not for long periods of time. In the village centre, there is an abandoned House of Trajko and Svetlana Denić, from 1845, but still with well-preserved old architecture. Bare walls reveal a strong timber framed structure (the post and beam with trusses or braces supporting at corner points) filled in with wattle and daub. The house doors have wooden keyholes, while the pitched roof is covered with stone.

In the part of the village called Šulenci is the House of Časlav Cacin, which is very similar to the house from Šugrin in terms of the construction type. The house has a cellar and a longitudinal wide porch on the ground floor, with pillars and decorative lintels, oriented towards the east. The separated part of the porch (the doksat), for sitting and relaxation is clearly defined. The house has stone roof covering, but the ceiling and the interior are damaged.

Deserted and dilapidated houses can also be seen in other of the villages in the Pirot area towards Knjaževac. Villages Ragodeš and Rudinje have characteristic houses with bay windows on all the house floors, which show unique tendencies of the native builders. Façades of the houses in Ragodeš are very rich in decorations; for instance, the House of Pera Lazarević has decorations in the shape of grape bunches on the attic above the door, which is a symbol of grapevine cultivation.

\section{CONCLUDING NOTE}

We can say that authentic and unique vernacular tradition, which determines the historical component of the life quality and the spirit of the times, has been preserved in the elements of traditional architecture in the Stara Planina villages, Serbia. Such architecture features traditional construction and materials, roof structures and covering, traditional architectural elements, like wooden porches and terrace galleries, with pillars and arches, traditional chimneys and fireplaces, and decorative elements like roof eaves wooden decoration and wooden elements on top of the pediment, etc. 
Unfortunately, this wealth of vernacular architectural heritage from the past two centuries has been fading with time, primarily due to the fact that the architecture was badly affected by mass migrations, unskilful and inappropriate adaptations of the existing structures and the socio-economic circumstances in the second half of the 20th century.

After the extensive research in the old Stara Planina villages, analysing a number of ruined and devastated residential houses and ancillary buildings, it becomes evident that the most authentic representatives of tradition (in terms of the wealth of architectural heritage and aesthetic forms) in the villages of Šugrin, Brlog, Ragodeš, Visočki Odorovci, Kamenica and Slavinja are in the process of disappearance. The same goes for the villages of Pokrvenik, Rosomač and Gostuša which, admittedly, do not feature any typified decorative features or typical traditional choices with regard to the materials and types of construction.

Preservation of the built heritage in the region of Stara Planina in its original form is very important for saving the vernacular heritage in Serbia, which is neglect and ruined. ${ }^{34}$ Learning the elements and methods of traditional architecture is very important for future generations because the principles of sustainability are recognized in many ways, such as (bio) degradability, recycling and re-use potentials of applied materials and structures, as well as reduction of adverse environmental impacts in all phases of the building life cycle. Relying on natural building materials, traditional builders ensured that their houses would be a healthy living space. ${ }^{35}$

Taking into consideration different approaches and the overall socio-economic situation in the Serbia, by setting up small architectural nuclei in the villages with exceptional traditional architectural features, it would be possible to preserve tradition or at least its image for future generations. This would necessitate adaptations of two or three authentic structures in the selected villages according to their original plans and with the application of the old methods of construction and building materials. In accordance with the geographical position of the selected villages, further steps would include connecting the newly-established architectural nuclei, thus forming architectural tourist route, which would be relevant for science and education (obligatory educational excursions of university students, public lectures on vernacular architecture, etc.), in addition to its tourism purposes. ${ }^{36}$ 
NOTES

N.B.

This paper is done as a part of a research project "Housing development in Serbia in the context of globalization and integrations" (No. TP36034) financed by the Ministry of Education, Science and Technologic Development of the Republic of Serbia.

Borislava Lilić, Istorija Pirota i okoline I deo: Pirot u periodu turske vlasti 1804-1878. (Pirot: NIPHemikals, "Grafika", 1994), 221.

At the Central register of immovable cultural heritage of Serbia in the Pirot Region are listed 31 buildings. See: http://www.heritage.gov.rs/cirilica/nepokretna_kulturna_dobra.php. Accessed $7^{\text {th }}$ April 2016.

Božidar Krstanović, "Rezultati istraživanja narodnog graditeljskog nasleđa," Glasnik DKS br. 27 (2003): 161-165.

Jovan Cvijić, Balkansko poluostrvo i južnoslovenske zemlje, knjiga 1 (Beograd: Zavod za udžbenike i nastavna sredstva, 2000), 22.

Gavrilo Vidanović Sazda, Visok (Beograd: Geografski institut SANU, Naučna knjiga, 1955), 44. Ibid, 159.

Branislav Kojić, Stara gradska i seoska arhitektura u Srbiji (Beograd: Prosveta, 1949), Aleksandar Deroko, Narodno neimarstvo I (Beograd: Srpska akademija nauka i umetnosti, 1968), Dobrivoje Pavlović et al., Narodno graditeljstvo na Balkanu (Beograd: RZZSKS, SANU, DKS, 1987).

Николай Тулешков, Славинските Първомайстори (София: Арх \&Aрт, 2007).

Borislava Lilić, Istorija Pirota i okoline II deo: Pirot u sastavu srpske države 1878-1918 godina, (Pirot: NIP Hemikals, "Grafika", 1994).

Gavrilo Vidanović Sazda, Visok, 69.

The tendency of population growth in Zabrđe and Visok in the 1884-1948 periods, marking a sharp population decline from 1910-1921, brought about by the losses in the First World War. In the following period, i.e. until 1948, a steady population growth was recorded (with high birth rates) which was, however, less than expected owing to the losses in the Second World War. From 1948 to date, there is a steady population decline leading to the villages dying away. See: Gavrilo Vidanović Sazda, Visok, 49-65, 151. Gavrilo Vidanović Sazda, Vidlič i Zabrđe (Beograd: SANU,Posebna izdanja knjiga CCCXXVII, Geografski institut, knjiga 15, Naučno delo, 1960), 43.

See: 1948 Census of FPRY population in: Gavrilo Vidanović Sazda, Visok, 63, and Gavrilo Vidanović Sazda, Vidlič i Zabrđe, 43. Population Comparative Overview in 1948, 1953, 1961, 1971, 1981, 1991, 2002 and 2011 in: 2011 Census of population, households and dwellings in the Republic of Serbia (Belgrade: Statistical Office of the Republic of Serbia, Vol. 20), 120-121.

G. Ljubenov have collected the material for this doctoral dissertation by visiting 36 villages in the Stara Planina area in the period from August, 2011 to June, 2014.

The villages belonging to Upper Visok are: Brlog, Visočaka Ržana, Jelovica, Dojkinci, Rsovci, Rosomač, Gostuša, Slavinja, Senokos, Kamenica, Braćevci, Izatovci, Gornji Krivodol, Donji Krivodol, Vlkovia.

The villages of Middle Visok are: Pakleštica, Bela, Zavoj, Velika Lukanja, Mala Lukanja, Koprivštica, Temska, Pokrovenik and Oreovica.

The villages of Lower Visok are: Zaskovci and Topli Do.

Branislav Kojić, Stara gradska i seoska arhitektura u Srbiji. Aleksandar Deroko, Narodno neimarstvo I. Dobrivoje St. Pavlović et al., Narodno graditeljstvo na Balkanu.

According to the data collected from the local population, 8 people lived in the village in September 2014.

Milica Jovanović-Popović, Bojana Stanković, Milica Pajkić, "Regional characteristics of individual housing units in Serbia from the aspect of applied building technologies, " SPATIUM International Review No. 31, (2014): 41.

Slobodan Nenadović, Ilustrovani rečnik izraza u narodnoj arhitekturi (Beograd: Prosveta, 2002), 293.

Francis D. K. Čing, Vizuelni rečnik arhitekture (Beograd: Građevinska knjiga, 2006), 166.

Aleksandar Ajzinberg, Stilovi arhitektura enterijer nameštaj terminološki rečnik (Beograd: Prosveta, 2007), 116; Francis D. K. Čing, Vizuelni rečnik arhitekture, 212. 
According to the local population, only 13 people lived in the village of Izatovci in August 2014. As the local population claim, no more than 3 people lived in the village in August 2014.

Village had only 2 inhabitants in August 2014.

Slobodan Nenadović, Ilustrovani rečnik izraza u narodnoj arhitekturi, 163.

Area of Zabrdje encompasses 9 villages: Radejna, Prtelaš, Smilovci, Visočki Odorovci, Gulenovci, Mazgoš, Mojinci, Brebevnica, Prtopopinci.

On the house's dormer, where two roof sides come together, there is an architectural element which the local people, out of mythological reasons, commonly call čuvar-kuća (house guard).

Unfortunately, in 2014, the demolition works on this structure started and that valuable vernacular architecture will be lost.

According to the unofficial data from September 2014, the village has about 60 inhabitants.

There were 17 people living in the village in December 2014.

Area of Budžak includes villages: Cerova, Mirkovci, Oreovica, Šugrin, Bazovik and Orlja.

Slobodan Nenadović, Ilustrovani rečnik izraza u narodnoj arhitekturi, 291.

For purposes of Serbian architectural heritage conservation, the Republic Institute for the Protection of Cultural Monuments initiated work on the Atlas of Vernacular Architecture of Serbia. Four volumes have been published: Požega, Vol. 1; Kragujevac, Vol. 2; Gornji Milanovac, Vol. 3; Užice and Čajetina, Vol. 4. The survey of the villages in Pirot and Dimitrovgrad municipalities, in the area of infrastructural corridor Niš - Bulgarian border, published in: B. Krstanović, "Research results with regard to vernacular architectural heritage," Glasnik društva konzervatora (the Gazette of the Society of Conservators of Serbia), Vol. 27 (2003): 161-165.

Ana Radivojević, Mirjana Roter-Blagojević, Aleksandar Rajčić, "Preservation of vernacular architecture in Serbia - authenticity versus thermal comfort issues", in: Proceedings of the International Conference on Structural Analysis of Historical Constructions, Volume III, SAHC 2012, 15-17 October 2012, Wroclaw, Poland, 2750-2759; Ana Radivojević, Mirjana Roter-Blagojević and Aleksandra Rajčić., "The issue of thermal performance and protection and modernization of traditional half-timbered (bondruk) style houses in Serbia," Journal of Architectural Conservation, vol. 20-3 (2014): 209-225.

The villages of Stara Planina are rich in vegetation and numerous animal and plant species, which represents a great potential for the development of mountain, hunting, rural and winter tourism. For this purpose and with regard to nature protection, the government of the Republic of Serbia adopted a Spatial Plan for the Special-Purpose Area of the Stara Planina Nature Park and Tourist Region. The plan prescribes all the measures of protection and revitalisation of the villages in the Stara Planina area. For instance, in the area of Visok 5 out of the total of 6 sectors of alpine ski resorts are envisaged (Topli Do, Dojkinci/Kopren, Jelovica/Rosomač, Mramor/Gostuša, Senokos/ Srebrna Glava). With the same aim Institute for Architecture and Urbanism of Serbia (IAUS) in 2007 published a study Rural infrastructure feasibility and costing study for the Stara Planina Mt. nature park under the auspices of the Ministry of Agriculture, Forestry and Water Management of the Republic of Serbia. The subjects of the study were the villages of Upper Visok, Dojkinci, Gostuša and Senokos. See: Maksin-Mićić et al., "Spatial and environmental planning of sustainable regional development in Serbia," SPATIUM International Review, No. 21 (2009): 39-52. 
Ajzinberg, Aleksandar. Stilovi arhitektura enterijer nameštaj terminološki rečnik. Beograd: Prosveta, 2007

Cvijić, Jovan. Balkansko poluostrvo i južnoslovenske zemlje, knjiga 1. Beograd: Zavod za udžbenike i nastavna sredstva, 2000.

Čing, Frensis. D. K. Vizuelni rečnik arhitekture. Beograd: Građevinska knjiga, 2006.

Deroko, Aleksandar. Narodno neimarstvo, knjiga 1. Beograd: Srpska akademija nauka i umetnosti, 1968.

Jovanović-Popović, Milica, Stanković, Bojana and Pajkić, Milica. "Regional characteristics of individual housing units in Serbia from the aspect of applied building technologies". SPATIUM International Review, No. 31 (2014): 39-44.

Kojić, Branislav. Stara gradska i seoska arhitektura u Srbiji. Beograd: Prosveta, 1949.

Krstanović, Božidar. "Rezultati istraživanja narodnog graditeljskog nasleđa". Glasnik DKS, br. 27 (2003): 161-165.

Maksin-Mićić, Marija, Milijić, Saška and Nenković-Riznić, Marina. "Spatial and environmental planning of sustainable regional development in Serbia". SPATIUM International Review, No. 21 (2009): 39-52.

Lilić, Borislava. Istorija Pirota i okoline I deo: Pirot u periodu turske vlasti 1804-1878. Pirot: NIPHemikals, "Grafika", 1994.

Lilić, Borislava. Istorija Pirota i okoline II deo: Pirot u sastavu srpske države 1878-1918 godina. Pirot: NIP Hemikals, "Grafika". 1994.

Nenadović, Slobodan M. Ilustrovani rečnik izraza u narodnoj arhitekturi. Beograd: Prosveta, 2002.

Николов, Весна. ”Археологицески находки на територията на община Димитровград”. Mocm, No. 180-191 (2005): 289-299.

Pavlović, Dobrivoje St., Angelova, Rahela, Micopulos, Nikola, Stojka, Žoržet and Haluk, Sezgin. Narodno graditeljstvo na Balkanu. Beograd: RZZSKS, SANU, DKS, 1987.

Protić, Miloje. Geološki sastav i tektonika Stare planine. Beograd: Geološki institut Kraljevine Jugoslavije, 1934.

Radivojević, Ana, Roter-Blagojević, Mirjana and Rajčić, Aleksandar. "Preservation of vernacular architecture in Serbia - authenticity versus thermal comfort issues". Proceedings of the International Conference on Structural Analysis of Historical Constructions, Volume III, SAHC 2012, October, 15-17 2012, Wroclaw, Poland: 2750-2759.

Radivojević, Ana, Roter-Blagojević, Mirjana and Rajčić, Aleksandar, "The issue of thermal performance and protection and modernization of traditional half-timbered (bondruk) style houses in Serbia”. Journal of Architectural Conservation, No. 20-3 (2014): 209-225.

Тулешков, Николай. Славинските Първомайстори. София: Арх \&Арт, 2007.

Vidanović, Gavrilo Sazda. Visok. Beograd: Geografski institut SANU, кnjiga 6, Naučna knjiga, 1955.

Vidanović, Gavrilo Sazda. Vidlič i Zabrđe. Beograd: SANU,Posebna izdanja knjiga CCCXXVII, Geografski institut, knjiga 15, Naučno delo, 1960. 